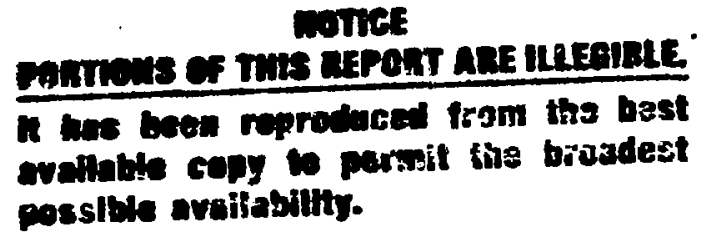

LA-10230-MS (ENDF-340)

UC-46

Issued: October 1984

LA- $-10230-\mathrm{I}: \mathrm{S}$

DE85 005233

\title{
Analysis of Central Worths and Other Integral Data from the Los Alamos Benchmark Assemblies
}

D. W. Muir

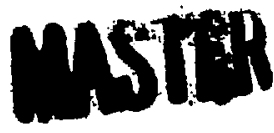




\section{DISCLAIMER}

This report was prepared as an account of work sponsored by an agency of the United States Government. Neither the United States Government nor any agency thereof, nor any of their employees, makes any warranty, express or implied, or assumes any legal liability $\mathrm{J}$. responsibility for the accuracy, completeness, or usefulness of any information, apparatus, product, or process disclosed, or represents that its use would not infringe privately owned rights. Reierence herein to any specific commercial product, process, or service by trade name, trademark, manufacturer, or otherwise does not necessaziiy constitute or imply its endorsement, recommendation, or favoring by the United States Government or any agency thereof. The views and opinions of authors expressed herein do not necessarily state or reflect those of the United States Government or any agency thereof. 
AHALYSIS OF CENTRAL WORTHS AND OTHER INTEGRAL DATA FROM THE LOS ALAïOS BENCHMARK ASSEMBLIES

\author{
by
}

D. W. Muir

\begin{abstract}
We have compared theoretical calculations, based on ENDF/B-V and recent revisions, witu integral data measured on the Los Alamos unmoderated critical assemblies Godiva, Jezebel, Flattop-25, and Flattop-Pu. The experimental data included in this analysis are multiplication factors $k_{\text {fff }}$ and (in most cases) both fission rates and cêftralworth ratios for ${ }^{235} \mathrm{U},{ }^{238} \mathrm{U},{ }^{237} \mathrm{~Np}$, and ${ }^{239} \mathrm{Pu}$. Based on this comparison, we conclude that there is a need for a new ${ }^{235} \mathrm{U}$ evaluation, and increased accuracy is needed in certain integral measurements.
\end{abstract}

\title{
I. INTRODUCTION
}

Because of the availability of recently revised nuclear-data evaluations, as well as recent additions and corrections to the body of integral data, it is of interest to re-examine the experimental data for the Los Alamos unmoderated critical assemblies Godiva, Jezebel, Flattop-25, and Flattop-Pu and to coupare these data with state-of-the-art theoretical predictions. The experimental data included in our analysis are multiplication factors $k$ eff and (in most cases) fission rates and worth ratios for ${ }^{235} \mathrm{U},{ }^{238} \mathrm{U},{ }^{237} \mathrm{~Np}$, and ${ }^{239} \mathrm{Pu}$. Preliminary numerical values of these measured quantities are given in Ref. 1 .

\section{CALCULATIONAL METHOD}

As a test of the standard approach (first-order perturbation theory) to the calculation of central worths, we have used the ONEDANT neutron transport. code, $^{2}$ together with TRANSX multigroup cross-section post-processing program, 3 to calculate all worths using the "direct" method. That is, we calculated $k_{\text {ef }}$ for a reference assembly with a very tight convergence criterion (EPSO $=10^{-5}$ ) 
and then recalculated it with the same criterion for a series of "perturbed" configurations. In all ONEDANT calculations, an $\mathbf{S}_{16}$ angular quadrature was employed.

The atomic compositions and radial dimensions of the one-dimensional models used in this study are given in Table $I$, which is adapted from Ref. 4. The geometrical meshes used in our ONEDANT runs were slightly different from those used in Ref. 4, which recommended a uniform mesh with 40 total intervals in both Godiva and Jezebel and a $30 / 30$ (core/reflector) mesh in the Flattops. The main difference is that in all of our calculations there was an "inner core" region, $0.5 \mathrm{~cm}$ in radius, finely zoned into 20 intervals. In Godiva and Jezebe1, the remainder of the assembly contained 40 equally spaced intervals. In the Flattops, two zoning strategies were employed outside the inner core. To save time, a relatively coarse mesh, consisting of 20 equally spaced intervals in the outer core and 20 in the reflector, was used in the lengthy perturbation series of calculations. A finer $20 / 40 / 40$ zoning was then used in a separate keff "benchmark" calculation.

TABLE I

BENCHMARK SPECIFICATIONS

\begin{tabular}{|c|c|c|c|c|c|c|c|}
\hline \multirow{2}{*}{ Material } & \multirow{2}{*}{ Godiva } & \multicolumn{2}{|c|}{ Flattop -25} & \multirow{2}{*}{ Jezebel } & \multicolumn{3}{|c|}{ Flattop-Pu } \\
\hline & & Core & Refl. & & Core & $i$ & $\operatorname{Re} f 1$ \\
\hline $\begin{array}{c}\mathrm{Ga} \\
\mathrm{U}-234 \\
\mathrm{U}-235 \\
\mathrm{U}-238 \\
\mathrm{Pu}-239 \\
\mathrm{Pu}-240 \\
\mathrm{Pu}-241\end{array}$ & $\begin{array}{l}0.000492 \\
0.04500 \\
0.002498\end{array}$ & $\begin{array}{l}0.00049 \\
0.04449 \\
0.00270\end{array}$ & $\begin{array}{l}0.00034 \\
0.04774\end{array}$ & $\begin{array}{l}0.03705 \\
0.001751 \\
0.000117\end{array}$ & $\begin{array}{l}0.03674 \\
0.00186 \\
0.00012\end{array}$ & 1 & $\begin{array}{l}0.00034 \\
0.04774\end{array}$ \\
\hline $\begin{array}{l}\text { Radius } \\
(\mathrm{cm})\end{array}$ & 8.741 & 6.116 & 24.13 & 6.385 & 4.533 & & 24.13 \\
\hline
\end{tabular}

In the perturbation series, the atomic density $\rho$ of a selected "perturbed nuclide" (not necessarily present in the reference assembly) was gradualiy increased from its reference value within the $0.5-\mathrm{cm}$ radius inner core until a net change in $k_{\text {eff }}$ of a few parts in $10^{4}$ was obtained. For ${ }^{235} \mathrm{v}$ and ${ }^{237} \mathrm{~Np}$, the set of density increments $\Delta \rho$ actually employed is $(0 ., 0.001,0.002,0.005$, 0.01 , and 0.02$)$, all expressed in units of atoms/barn-cm. For ${ }^{238} \mathrm{v}$, the set 
used is $(0 ., 0.005,0.01,0.02,0.05$, and 0.1$)$ and for ${ }^{239} \mathrm{Pu}(0 ., 0.0005$, $0.001,0.002,0.005$, and 0.01 ). The perturbed nuclide was added "interstitia1ly," that is, without simultaneously removing other materials from the reference assembly. This procedure should provide a reliable estimate of the initial slope

$$
\left.\frac{d k}{d \rho}\right|_{\rho}=0,
$$

which is identical, excep = for a multiplicative factor, to the "reactivity coefficient" normally quoted. In addition, our results may provide a useful calculational benchmark for testing various perturbation-theory methods for predicting the value of the second derivative

$$
\left.\frac{d^{2} k}{d \rho^{2}}\right|_{\rho=0}
$$

\section{NUCLEAR DATA}

The cross sections used for neutron transport in the materials of a given reference assembly were either (a) original ENDF/B-V for all materials or (b) ENDF/B-V for all materials but ${ }^{239} \mathrm{Pu}$, and Revision 2 of ENDF/B-V for that nuclide. The cross sections for four of the perturbed naclides were taken from original ENDF/B-V: ${ }^{235} \mathrm{U}(25),{ }^{238} \mathrm{U}(28),{ }^{237} \mathrm{~Np}(37)$, and ${ }^{239} \mathrm{Pu}$ (49). In addition, and treated as data for distinct perturbed nuclides, were a recent T-2 reevaluation ${ }^{5}$ for ${ }^{237} \mathrm{~Np}(37 \mathrm{~A})$ and the new Revision 2 evaluation ${ }^{6}$ for ${ }^{239} \mathrm{Pu}$ (49A). Thus, there were six reference "assemblies," namely, Godiva, Flattop-25, Jezebel(V), Flattop-Pu(V), Jezebel(V.2), and Flattop-Pu(V.2), and six perturbed "nuclides," namely, 25, 28, 37, 37A, 49, and 49A.

Cross-section sets for all materials contained in Godiva, Jezebel, and the two Flattops (see Table I), plus ${ }^{237} \mathrm{~Np}$, were already available ${ }^{5}$ in the Los Alamos 80-group neutron structure. The GENDF files discussed in Ref. 5 were retrieved and merged into a single GENDF. This was, in turn, converted to MATXS format using the NMATXS module of NJOY (Ref. 7). The resulting MATXSformatted library, called MATXS80, is available on request. MATXS80 was read repeatedly with the TRANSX ${ }^{3}$ program, in order to generate perturbed cross-section sets in the XSLIB format, one of the cross-section input formats read by ONEDANT. $\quad P_{3}$ transport-corrected tables were produced using the Bell-HansenSandmeier formulation. 
IV. RESULTS

For each of the six reference assemblies, we perforned one unperturbed ONEDANT $k$-calculation and 30 perturbed $k$-calculations $(6$ nuclides $\times 5$ nonzero densities).

The six $k_{\text {eff }}$ values obt.ained for a given assembly/nuclide combination were then fit with a second-order polynomial,

$$
k_{e f f}(p) \cong A+B \rho+C \rho^{2}
$$

using an unweighted least-squares algorithm. The results of recalculating $k_{\text {eff }}$ values with these $A, L$, and $C$ values, when rounded to the eight digits supplied on the ONEDANT output listing, wre in perfect agreement with the ONEDANT values. Thus, no evidence was found for irregularities in the $\rho$ dependence, and furthermore, no evidence was found for the presence of a $\rho^{3}$ contribution. The maximum deviation from linearity, that is,

$$
\left.\frac{C \rho^{2}}{B \rho}\right|_{\rho=\rho_{\max }}
$$

was around $10 \%$ for ${ }^{238} \mathrm{U}$ and less than $2 \%$ for all other perturbed nuclides. A complete list of the $A, B$, and $C$ values obtained for the six reference assemblies and the six perturbed nuclides is given in Table II.

From the form of Eq. (1), it is clear that $\left.\frac{d k}{d \rho}\right|_{\rho=0}=B$.

Thus, the values of $B$ in Table II can easily be converted to absolute reactivity coefficients, in units of $\$ / \mathrm{kg}$ or $\$ / \mathrm{mole}$. However, for the purposes of data testing, the main information is contained in worth ratios such as

$$
\frac{\Delta \mathrm{k}(28)}{\Delta \mathrm{k}(25)}=\frac{\left.\frac{\partial \mathrm{k}}{\partial \rho_{28}}\right|_{\rho_{28}}}{\left.\frac{\partial \mathrm{k}}{\partial \rho_{25}}\right|_{\rho_{25}}=0}=\frac{\mathrm{B}(28)}{\mathrm{B}(25)}
$$

For a variety of reasons, these ratios can be measured and calculated much more accurately than the corresponding absolute values. 
TABLE II

QUADRATIC FITS TO $k_{\text {eff }}(\rho)$

Unreflected Assemblies

\begin{tabular}{|c|c|c|c|c|c|}
\hline Assembly & $\begin{array}{l}{ }^{23{ }^{9}} \mathrm{Pu} \text { Data } \\
\text { Source } \\
\end{array}$ & $\begin{array}{l}\text { Perturbed } \\
\text { Nuclide }\end{array}$ & $\begin{array}{l}\text { Coeffi } \\
\mathrm{A}\end{array}$ & $\begin{array}{l}\text { ents for Quadr } \\
\text { B } \\
\end{array}$ & $\begin{array}{r}\text { Itic Fit } \\
\mathrm{C}\end{array}$ \\
\hline Godiva & - & $\begin{array}{l}25 \\
28 \\
37 \\
37 \mathrm{~A} \\
49 \\
49 \mathrm{~A}\end{array}$ & $\begin{array}{l}0.9990101 \\
0.9990101 \\
0.9990101 \\
0.9990101 \\
0.9990101 \\
0.9990101\end{array}$ & $\begin{array}{l}8.68055 \mathrm{E}-03 \\
1.42763 \mathrm{E}-03 \\
9.37291 \mathrm{E}-03 \\
8.88699 \mathrm{E}-03 \\
1.69314 \mathrm{E}-02 \\
1.67967 \mathrm{E}-02\end{array}$ & $\begin{array}{r}7.84769 \mathrm{E}-03 \\
-1.02810 \mathrm{E}-03 \\
5.80292 \mathrm{E}-03 \\
6.52704 \mathrm{E}-03 \\
2.93684 \mathrm{E}-02 \\
2.91364 \mathrm{E}-02\end{array}$ \\
\hline Jezebel & Vers. V & $\begin{array}{l}25 \\
28 \\
37 \\
37 A \\
49 \\
49 A\end{array}$ & $\begin{array}{l}1.0068215 \\
1.0068215 \\
1.0068215 \\
1.0068215 \\
1.0068215 \\
1.0068215\end{array}$ & $\begin{array}{l}1.37306 \mathrm{E}-02 \\
1.77769 \mathrm{E}-03 \\
1.51790 \mathrm{E}-02 \\
1.48062 \mathrm{E}-02 \\
2.72345 \mathrm{E}-02 \\
2.70808 \mathrm{E}-02\end{array}$ & $\begin{array}{r}1.32492 \mathrm{E}-02 \\
-1.62518 \mathrm{E}-03 \\
1.02638 \mathrm{E}-02 \\
1.15023 \mathrm{E}-02 \\
4.87334 \mathrm{E}-02 \\
4.82577 \mathrm{E}-02\end{array}$ \\
\hline Jezebel & Vers. V.2 & $\begin{array}{l}25 \\
28 \\
37 \\
37 \mathrm{~A} \\
49 \\
49 \mathrm{~A}\end{array}$ & $\begin{array}{l}0.9981936 \\
0.9981936 \\
0.9981936 \\
0.9981936 \\
0.9981936 \\
0.9981936\end{array}$ & $\begin{array}{l}1.36989 \mathrm{E}-02 \\
2.06169 \mathrm{E}-03 \\
1.55140 \mathrm{E}-02 \\
1.51022 \mathrm{E}-02 \\
2.70810 \mathrm{E}-02 \\
2.69001 \mathrm{E}-02\end{array}$ & $\begin{array}{r}1.27073 \mathrm{E}-02 \\
-1.71336 \mathrm{E}-03 \\
1.01502 \mathrm{E}-02 \\
1.16815 \mathrm{E}-02 \\
4.82907 \mathrm{E}-02 \\
4.75891 \mathrm{E}-02\end{array}$ \\
\hline
\end{tabular}

\section{${ }^{238} \mathrm{U}$-Reflected Assemblies}

\begin{tabular}{|c|c|c|c|c|c|}
\hline Assembly & $\begin{array}{l}{ }^{239} \text { Pu Data } \\
\text { Source }\end{array}$ & $\begin{array}{l}\text { Perturbed } \\
\text { Nuclide } \\
\end{array}$ & $\begin{array}{l}\text { Coef } \\
\mathrm{A}\end{array}$ & $\begin{array}{c}\text { ats for Quad } \\
\text { B } \\
\end{array}$ & $\begin{array}{r}\text { tic Fit } \\
\mathrm{C}\end{array}$ \\
\hline Flattop-25 & - & $\begin{array}{l}25 \\
28 \\
37 \\
37 A \\
49 \\
49 A\end{array}$ & $\begin{array}{l}1.0068629 \\
1.0068629 \\
1.0068629 \\
1.0068629 \\
1.0068629 \\
1.0068629\end{array}$ & $\begin{array}{l}1.16395 E-02 \\
1.52562 E-03 \\
1.13477 E-02 \\
1.07433 E-02 \\
2.25613 E-02 \\
2.24567 E-02\end{array}$ & $\begin{array}{r}1.00985 \mathrm{E}-02 \\
-1.19445 \mathrm{E}-03 \\
7.43018 \mathrm{E}-03 \\
7.88823 \mathrm{E}-03 \\
3.98072 \mathrm{E}-02 \\
3.65544 \mathrm{E}-02\end{array}$ \\
\hline Flattop-Pu & Vers. V & $\begin{array}{l}25 \\
28 \\
37 \\
37 \mathrm{~A} \\
49 \\
49 \mathrm{~A}\end{array}$ & $\begin{array}{l}1.0110740 \\
1.0110740 \\
1.0110740 \\
1.0110740 \\
1.0110740 \\
1.0120740\end{array}$ & $\begin{array}{l}2.04223 \mathrm{E}-02 \\
1.94535 \mathrm{E}-03 \\
1.94664 \mathrm{E}-02 \\
1.88847 \mathrm{E}-02 \\
3.96966 \mathrm{E}-02 \\
3.95522 \mathrm{E}-02\end{array}$ & $\begin{array}{r}1.81521 \mathrm{E}-02 \\
-1.90635 \mathrm{E}-03 \\
1.33902 \mathrm{E}-02 \\
1.55448 \mathrm{E}-02 \\
7.21276 \mathrm{E}-02 \\
6.97789 \mathrm{E}-02\end{array}$ \\
\hline Flattop-Pu & Vers. V.2 & $\begin{array}{l}25 \\
28 \\
37 \\
37 A \\
49 \\
49 A\end{array}$ & $\begin{array}{l}1.0068004 \\
1.0068004 \\
1.0068004 \\
1.0068004 \\
1.0068004 \\
1.0068004\end{array}$ & $\begin{array}{l}2.01940 E-02 \\
2.19862 E-03 \\
1.96487 E-02 \\
1.90449 E-02 \\
3.92521 E-02 \\
3.90782 E-02\end{array}$ & $\begin{array}{r}1.75363 \mathrm{E}-02 \\
-2.01891 \mathrm{E}-03 \\
1.29878 \mathrm{E}-02 \\
1.51980 \mathrm{E}-02 \\
6.83868 \mathrm{E}-02 \\
6.69841 \mathrm{E}-02\end{array}$ \\
\hline
\end{tabular}

a "Data" here refers to the bulk-transport cross sections, which were held constant during a series of perturbation calculations. 
As a final step in the calculation of worth ratios, in the case of the new neptunium evaluation ${ }^{5}$ it was necessary to estimate the relative worth of delayed neutrons from fission of ${ }^{237} \mathrm{~Np}$, because the GENDF nultigroup fission matrices did not contain delayed neutrons in this case. This effect is estimated to increase $\Delta \mathrm{k}(37 \mathrm{~A}) / \Delta \mathrm{k}(25)$ by a factor of 1.01 with an uncertainty of about $0.5 \%$, which is smaller than the uncertainty of the corresponding measurements.

In Table III, results are presented for the calculated and measured (Ref. 1) worth ratios and fission ratios for the two ${ }^{235} \mathrm{U}$-fueled assemblies, Godiva and Flattop-25. In all cases where an ENDF/B-V "nuclide" is placed in an ENDF/B-V "assembly," it is possible to compare our results, obtained using the direct method, with the results (shown in parentheses) obtained in Ref. 4 using first-order perturbation theory (and using a slightly different group structure, plus other minor calculational differences). The agreement is excellent, and this adds confidence in both the results of the current study and those reported in Ref. 4.

Since Flattop-25 has a ${ }^{238} \mathrm{U}$ reflector, the central neutron flux is somewhat softer than in Godiva. This is manifested in Table III by the lower worth and fission ratios for the threshold fissioners $\left({ }^{238} \mathrm{U}\right.$ and $\left.{ }^{237} \mathrm{~Np}\right)$ in Flattop-25. Another obvious feature of these results is that the $\mathrm{C} / \mathrm{E}$ values for the worth and fission ratios are systematically high in both assemblies for these same nuclides. It is clear that modification of the ${ }^{235} \mathrm{U}$ transport cross sections in some fashion, so as to soften the central flux, would improve the agreement of the calculated results with the measurements. Another clear result is that the new neptunium evaluation performs considerably better here than does the ENDF/B-V evaluation. It is not possible, at this point, to say whether the remaining neptunium discrepancies (for example, the $\mathrm{C} / \mathrm{E}$ value of $1.09 \pm 0.01$ for $\Delta k(37 \mathrm{~A}) / \Delta \mathrm{k}(25)$ in Flattop-25) are due entirely to the ${ }^{235} \mathrm{U}$ spectrum effect or whether they are partially caused by remaining problems in ${ }^{237} \mathrm{~Np}$. This question can only be answered when an improved evaluation for ${ }^{235} \mathrm{U}$ becomes available.

In Table IV are given the results for the two ${ }^{239}$ Pu-fueled assemblies, where the reference cross sections for ${ }^{239} \mathrm{Pu}$ are the original ENDF/B-V data. Here there is evidence in the fission ratios for ${ }^{238_{\mathrm{U}}}$ and ${ }^{237} \mathrm{~Np}$ that the calculated central spectrum is too soft. This trend was part of the motivation for a recent re-examination of the ${ }^{239} \mathrm{Pu}$ data situation. The result of this work ${ }^{6}$ is the ${ }^{239} \mathrm{Pu}$ evaluation issued in Revision 2 of ENDF/B-V. 
TABLE III

RESULTS FOR ${ }^{235} \mathrm{U}$ ASSEMBLIES

Godiva

\begin{tabular}{|c|c|c|c|c|c|c|}
\hline Quantity & Calculation & Measurenent & $\underline{\mathrm{C} / \mathrm{E}}$ & Calculation & Measurement & $\underline{\mathrm{C} / \mathrm{E}}$ \\
\hline $\begin{array}{l}\Delta k(28) / \Delta k(25) \\
\sigma_{f}(28) / \sigma_{f}(25)\end{array}$ & $\begin{array}{l}0.1645(0.1642) \\
0.1704(0.1707)\end{array}$ & $\begin{array}{l}0.1606 \pm 2.2 \% \\
0.1643 \pm 1.1 \%\end{array}$ & $\begin{array}{l}1.024 \\
1.037\end{array}$ & $\begin{array}{l}0.1311(0.1303) \\
0.1541(0.1547)\end{array}$ & $\begin{array}{l}0.1238 \pm 4.1 \% \\
0.1492 \pm 1.1 \%\end{array}$ & $\begin{array}{l}1.059 \\
1.033\end{array}$ \\
\hline $\begin{array}{l}\Delta k(37) / \Delta k(25) \\
\sigma_{f}(37) / \sigma_{f}(25)\end{array}$ & $\begin{array}{l}1.080 \\
0.889(0.891)\end{array}$ & $0.852 \pm 1.4 \%$ & $\overline{1.044}$ & $\begin{array}{l}0.975(0.979) \\
0.822(0.826)\end{array}$ & $\begin{array}{l}0.856 \pm 0.7 \% \\
0.780 \pm 1.3 \%\end{array}$ & $\begin{array}{l}1.139 \\
1.054\end{array}$ \\
\hline $\begin{array}{l}\Delta k(37 A) / \Delta k(25) \\
\sigma_{f}(37 A) / \sigma_{f}(25)\end{array}$ & $\begin{array}{l}1.034 \pm 0.5 \% \\
0.881\end{array}$ & $0.852 \pm 1.4 \%$ & $\overline{1.034}$ & $\begin{array}{l}0.932 \pm 0.5 \% \\
0.814\end{array}$ & $\begin{array}{l}0.856 \pm 0.7 \% \\
0.780 \pm 1.3 \%\end{array}$ & $\begin{array}{l}1.089 \\
1.044\end{array}$ \\
\hline $\begin{array}{l}\Delta k(49) / \Delta k(25) \\
\sigma_{f}(49) / \sigma_{f}(25)\end{array}$ & $\begin{array}{l}1.950(1.952) \\
1.393(1.394)\end{array}$ & $\begin{array}{l}1.914 \pm 1.4 \% \\
1.415 \pm 1.0 \%\end{array}$ & $\begin{array}{l}1.019 \\
0.984\end{array}$ & $\begin{array}{l}1.938(1.945) \\
1.370(1.371)\end{array}$ & $\begin{array}{l}1.900 \pm 0.7 \% \\
1.385 \pm 0.9 \%\end{array}$ & $\begin{array}{l}1.020 \\
0.989\end{array}$ \\
\hline $\begin{array}{l}\Delta k(49 A) / \Delta k(25) \\
\sigma_{f}(49 A) / \sigma_{f}(25)\end{array}$ & $\begin{array}{l}1.935 \\
1.393\end{array}$ & $\begin{array}{l}1.914 \pm 1.4 \% \\
1.415 \pm 1.0 \%\end{array}$ & $\begin{array}{l}1.011 \\
0.984\end{array}$ & $\begin{array}{l}1.929 \\
1.370\end{array}$ & $\begin{array}{l}1.900 \pm 0.7 \% \\
1.385 \pm 0.9 \%\end{array}$ & $\begin{array}{l}1.015 \\
0.989\end{array}$ \\
\hline$k_{\text {eff }}$ (fine) & $0.9901(1.0028)$ & $1.0000 \pm 0.10 \%$ & 0.9901 & $1.0062(1.0149)$ & $1.0000 \pm 0.10 \%$ & 1.0062 \\
\hline
\end{tabular}


TABLE IV

RESULTS FOR ${ }^{239} \mathrm{Pu}$ ASSEMBLIES CALCULATED WITH ORIGINAL ENDF/B-V ${ }^{239}$ Pu REFERENCE CROSS SECTIONS

Jezebel(V)

\begin{tabular}{|c|c|c|c|c|c|c|}
\hline \multirow[b]{2}{*}{ Quantity } & \multicolumn{3}{|c|}{ Jezebel(V) } & \multicolumn{3}{|c|}{ Flattop-Pu(V) } \\
\hline & Calculation & Measurement & $\underline{\mathrm{C} / \mathrm{E}}$ & Calculation & Measurement & $\underline{C} / \mathrm{E}$ \\
\hline $\begin{array}{l}\Delta k(28) / \Delta k(25) \\
\sigma_{f}(28) / \sigma_{f}(25)\end{array}$ & $\begin{array}{l}0.1295(0.1287) \\
0.1958(0.1959)\end{array}$ & $\begin{array}{l}0.1390 \pm 2.0 \% \\
0.2133 \pm 1.1 \%\end{array}$ & $\begin{array}{l}0.932 \\
0.918\end{array}$ & $\begin{array}{l}0.0953(0.0937) \\
0.1684(0.1693)\end{array}$ & $\begin{array}{l}0.0940 \pm 3.8 \% \\
0.1799 \pm 1.1 \%\end{array}$ & $\begin{array}{l}1.014 \\
0.936\end{array}$ \\
\hline $\begin{array}{l}\Delta k(37) / \Delta k(25) \\
\sigma_{f}(37) / \sigma_{f}(25)\end{array}$ & $\begin{array}{l}1.106(1.107) \\
0.950(0.952)\end{array}$ & $\begin{array}{l}1.030 \pm 6.0 \% \\
0.984 \pm 1.4 \%\end{array}$ & $\begin{array}{l}1.074 \\
0.966\end{array}$ & $\begin{array}{l}0.953(0.958) \\
0.847(0.852)\end{array}$ & $\begin{array}{l}0.944 \pm 1.1 \% \\
0.856 \pm 1.4 \%\end{array}$ & $\begin{array}{l}1.010 \\
0.989\end{array}$ \\
\hline $\begin{array}{l}\Delta k(37 A) / \Delta k(25) \\
\sigma_{f}(37 A) / \sigma_{f}(25)\end{array}$ & $\begin{array}{l}1.089 \pm 0.5 \% \\
0.943\end{array}$ & $\begin{array}{l}1.030 \pm 6.0 \% \\
0.984 \pm 1.4 \%\end{array}$ & $\begin{array}{l}1.057 \\
0.959\end{array}$ & $\begin{array}{l}0.934 \pm 0.5 \% \\
0.839\end{array}$ & $\begin{array}{l}0.944 \pm 1.1 \% \\
0.856 \pm 1.4 \%\end{array}$ & $\begin{array}{l}0.990 \\
0.980\end{array}$ \\
\hline $\begin{array}{l}\Delta k(49) / \Delta k(25) \\
\sigma_{f}(49) / \sigma_{f}(25)\end{array}$ & $\begin{array}{l}1.984(1.985) \\
1.407(1.408)\end{array}$ & $\begin{array}{l}1.996 \pm 1.4 \% \\
1.461 \pm 0.9 \%\end{array}$ & $\begin{array}{l}0.994 \\
0.963\end{array}$ & $\begin{array}{l}1.944(1.952) \\
1.370(1.372)\end{array}$ & $\begin{array}{c}1.934 \pm 1.1 \% \\
-\end{array}$ & 1.005 \\
\hline $\begin{array}{l}\Delta k(49 A) / \Delta k(25) \\
\sigma_{f}(49 A) / \sigma_{f}(25)\end{array}$ & $\begin{array}{l}1.972 \\
1.407\end{array}$ & $\begin{array}{l}1.996 \pm 1.4 \% \\
1.461 \pm 0.9 \%\end{array}$ & $\begin{array}{l}0.988 \\
0.963\end{array}$ & $\begin{array}{l}1.937 \\
1.370\end{array}$ & $\begin{array}{c}1.934 \pm 1.1 \% \\
-\end{array}$ & 1.002 \\
\hline$k_{\text {eff }}(f i n e)$ & $1.0068(1.0111)$ & $1.0000 \pm 0.20 \%$ & 1.0068 & $1.0099(1.0207)$ & $1.0000 \pm 0.14 \%$ & 1.0099 \\
\hline
\end{tabular}

Flattop-Pu(V) 
Adopting the Revision 2 evaluation as the reference, one obtains the results given in Table $V$. There is noticeable improvement here in the fission ratios for ${ }^{238} \mathrm{U}$ and ${ }^{237} \mathrm{~Np}$. The "benchmark" (fine-mesh) calculations of $k_{\text {eff }}$ are also now in better agreement with the measurements.

However, the situation with the ${ }^{238} \mathrm{U}$ and ${ }^{237} \mathrm{~Np}$ worths is not as good. In these calculations, using the latest ${ }^{239} \mathrm{Pu}$ evaluation to calculate the central neutron spectrum and the latest cross sections for the threshold fissioners, we still have a $\mathrm{C} / \mathrm{E}$ of $1.16 \pm 0.04$ for the ${ }^{238} \mathrm{U} /{ }^{235} \mathrm{U}$ worth ratio in Flattop-Pu $(V .2)$ and a $C / E$ of $1.08 \pm 0.06$ for ${ }^{237} \mathrm{~Np} /{ }^{235} \mathrm{U}$ in Jezebel(V.2). It is interesting that the more discrepant $\mathrm{C} / \mathrm{E}$ occurs in the relatively soft Flattop-Pu spectrum for ${ }^{238} \mathrm{v}$ and in the harder Jezebel spectrum for ${ }^{237} \mathrm{~Np}$. From this, it is clear that "fine tuning" of the ${ }^{239} \mathrm{Pu}$ spectrum cannot solve both problems simultareously. Although it is risky to try to explain discrepancies in complex systems in terms of just a few cross sections, one could speculate that there are problems in the ${ }^{238} \mathrm{U}$ cross sections at low energies and/or some slight problems in ${ }^{237} \mathrm{~Np}$ at higher energies. Any stronger conclusion than this must await the availability of worth-ratio measurements with higher accuracy.

It is also of interest to note the slight, but systematic, discrepancies in the Jezebel fission ratios. It is difficult to think of a single change that would improve all three ratios, other than a $3 \%$ lowering of the $235 \mathrm{U}$ fission cross section in a Jezebel-type spectrum. This large a change would be at the outer limits of the uncertainty specified by the ENDF/B-V evaluators. Because of the close connection between $\sigma_{f}$ and worth, such a change would aggravate the worth-ratio discrepancies just discussed.

An overall trend worth mentioning is that the addition of the ${ }^{238} \mathrm{U}$ reflector (for example, Godiva $\rightarrow$ Flattop-25) has the effect, in each case, of raising the $k_{\text {eff }} \mathrm{C} / \mathrm{E}$ ratio and in all cases this is a change for the worse. This trend reinforces the earlier suggestion of problems in the ${ }^{238} \mathrm{U}$ cross sections at the lower energies.

Another point of interest is that the rising ${ }^{238} \mathrm{v}$ worth-ratio $\mathrm{C} / \mathrm{E}$ values in the series [Godiva, Flattop-25, Jezebel(V.2), Flattop-Pu(V.2)] are strongly correlated with rising ${ }^{238_{U}}$ (absolute) worths in these assemblies (see Table II). Although many explanations could be offered for this correlation, at least one possibility worth examining is difficulties in the experimental data reduction such as the treatment of nonlinear effects, which are especially important for ${ }^{238} \mathrm{v}$. 
TABLE V

RESULTS FOR ${ }^{239} \mathrm{Pu}$ ASSEMBLIES CALCULATED WITH ENDF/B-V, REVISION 2, ${ }^{239}$ Pu REFERENCE CROSS SECTIONS Jezebel (V.2)

Elattop-Pu(V.2)

\begin{tabular}{|c|c|c|c|c|c|c|}
\hline Quantity & Calculation & Measurement & $\underline{\mathrm{C} / \mathrm{E}}$ & Calculation & Measurement & $\mathrm{C} / \mathrm{E}$ \\
\hline $\begin{array}{l}\Delta k(28) / \Delta k(25) \\
\sigma_{f}(28) / \sigma_{f}(25)\end{array}$ & $\begin{array}{l}0.1505 \\
0.2050\end{array}$ & $\begin{array}{l}0.1390 \pm 2.0 \% \\
0.2133 \pm 1.1 \%\end{array}$ & $\begin{array}{l}1.083 \\
0.961\end{array}$ & $\begin{array}{l}0.1089 \\
0.1750\end{array}$ & $\begin{array}{l}0.0940 \pm 3.8 \% \\
0.1799 \pm 1.1 \%\end{array}$ & $\begin{array}{l}1.159 \\
0.973\end{array}$ \\
\hline $\begin{array}{l}\Delta k(37) / \Delta k(25) \\
\sigma_{f}(37) / \sigma_{f}(25)\end{array}$ & $\begin{array}{l}1.132 \\
0.963\end{array}$ & $\begin{array}{l}1.030 \pm 6.0 \% \\
0.984 \pm 1.4 \%\end{array}$ & $\begin{array}{l}1.099 \\
0.979\end{array}$ & $\begin{array}{l}0.973 \\
0.856\end{array}$ & $\begin{array}{l}0.944 \pm 1.1 \% \\
0.856 \pm 1.4 \%\end{array}$ & $\begin{array}{l}1.031 \\
1.000\end{array}$ \\
\hline $\begin{array}{l}\Delta k(37 A) / \Delta k(25) \\
\sigma_{f}(37 A) / \sigma_{f}(25)\end{array}$ & $\begin{array}{l}1.113 \pm 0.5 \% \\
0.957\end{array}$ & $\begin{array}{l}1.030 \pm 6.0 \% \\
0.984 \pm 1.4 \%\end{array}$ & $\begin{array}{l}1.081 \\
0.973\end{array}$ & $\begin{array}{l}0.952 \pm 0.5 \% \\
0.849\end{array}$ & $\begin{array}{l}0.944 \pm 1.1 \% \\
0.856 \pm 1.4 \%\end{array}$ & $\begin{array}{l}1.009 \\
0.992\end{array}$ \\
\hline $\begin{array}{l}\Delta k(49) / \Delta k(25) \\
\sigma_{f}(49) / \sigma_{f}(25)\end{array}$ & $\begin{array}{l}1.977 \\
1.411\end{array}$ & $\begin{array}{l}1.996 \pm 1.4 \% \\
1.461 \pm 0.9 \%\end{array}$ & $\begin{array}{l}0.990 \\
0.966\end{array}$ & $\begin{array}{l}1.944 \\
1.373\end{array}$ & $1.934 \pm 1.1 \%$ & 1.005 \\
\hline $\begin{array}{l}\Delta k(49 A) / \Delta k(25) \\
\sigma_{f}(49 A) / \sigma_{f}(25)\end{array}$ & $\begin{array}{l}1.964 \\
1.411\end{array}$ & $\begin{array}{l}1.996 \pm 1.4 \% \\
1.461 \pm 0.9 \%\end{array}$ & $\begin{array}{l}0.984 \\
0.966\end{array}$ & $\begin{array}{l}1.935 \\
1.373\end{array}$ & $1.934 \pm 1.1 \%$ & 1.001 \\
\hline $\mathbf{k}_{\text {eff }}$ (fine) & 0.9982 & $1.0000 \pm 0.20 \%$ & 0.9982 & 1.0056 & $1.0000 \pm 0.14 \%$ & 1.0056 \\
\hline
\end{tabular}




\section{CONCLUSTONS}

By the use of a straightforward direct method, we have validated the worth ratios previously calculated ${ }^{4}$ using first-order perturbation theory. In the area of nuclear data, we see evidence for the need to revise the ${ }^{235} \mathrm{U}$ cross sections, both to soften the central neutron spectrum in ${ }^{235} \mathrm{U}$-fueled assemblies and to reduce the average ${ }^{235} \mathrm{U}$ fission cross section in ${ }^{239} \mathrm{Pu}$-fueled assemblies. We find that the new ${ }^{239} \mathrm{Pu}$ evaluation ${ }^{6}$ improves the $\mathrm{C} / \mathrm{E}$ values in most respects, although the high $\mathrm{C} / \mathrm{E}$ values for the worth ratios of threshold fissioners are not understood. We find that the new ${ }^{237}$ Np evaluation ${ }^{5}$ offers improvements in most areas over the ENDF/B-V evaluation and that ${ }^{237} \mathrm{NP} \mathrm{C} / \mathrm{E}$ ratios are generally superior to the corresponding ${ }^{238} \mathrm{U}$ values. Detailed recommendations for futher improvements in the data for the threshold fissioners must await improvements in the ${ }^{235} \mathrm{U}$ evaluation and in the accuracy of some of the integral measurements. 


\section{REFERENCES :}

1. R. E. MacFarlane, D. W. Muir, and G. E. Hansen, in E. D. Arthur and A. Mutschlecner, Comps., "Applied Nuclear Data Research and Development SemiAnnual Progress Report October 1, 1983-May 31, 1984, Los Alamos National Laboratory report (to be published).

2. R. Douglas O'Dell, Forrest W. Brinkley, Jr., and Duane R. Marr, "User's Manual for ONEDANT: A Code Package for One-Dimensional, Diffusion-Accelerated, Nentral-Particle Transport," Los ATamos National Laboratory report

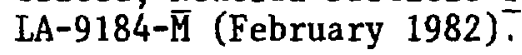

3. R. E. MacFarlane, "TRANSX-CTR: A Code for Interfacing MATXS Cross-Section Libraries to Nuclear Transport Codes for Fusion Systems Analysis," Los Alamos National Laboratory report LA-9863-MS (February 1984).

4. R. B. Kidman, "Los Alamos Benchmarks: Calculations Based on ENDF/B-V Data," Los Alamos National Laboratory report LA-9037-MS (ENDF-318) (November 1981).

3. Los Alamos National Laboratory memorandum (T-2-M-1467), "Revised ${ }^{237} \mathrm{~Np}$ Evaluation," to R. Little, X-6, from E. Arthur and R. MacFarlane, T-2, March 19, 1984.

6. E. D. Arthur, P. G. Young D. G. Madland, and R. E. MacFarlane, "Evaluation and Testing of $n+{ }^{239} \mathrm{Pu}$ Nuclear Data for Revision 2 of ENDF/B-V," to be published in Nucl. Sui. Eng. (1984).

7. R. E. MacFarlane, D. W. Muir, and R. M. Boicourt, "The NJOY Nuclear Data Processing System, Volume I: User's Manual," Los Alamos National Laboratory report LA-9303-M, Vol. I (ENDF-324) (May 1982). 